\title{
The challenges and promises of allogeneic mesenchymal stem cells for use as a cell-based therapy
}

\author{
Jun Zhang ${ }^{1,2,3}$, Xiaowen Huang ${ }^{2}$, Haijun Wang ${ }^{2}$, Xiaoyan Liư ${ }^{4}$ Tao Zhang ${ }^{5}$, Yunchuan Wang ${ }^{\text {* }}$ and Dahai Hu ${ }^{\text {* }}$
}

\begin{abstract}
Mesenchymal stem cells (MSCs) are ideal for cell-based therapy in various inflammatory diseases because of their immunosuppressive and tissue repair properties. Moreover, their immunosuppressive properties and low immunogenicity contribute to a reduced or weakened immune response elicited by the implantation of allogeneic MSCs compared with other cell types. Therefore, implantation of allogeneic MSCs may be a promising cell-based therapy. In this review, we first summarize the unique advantages of allogeneic MSCs for therapeutic applications. Second, we critically analyze the factors influencing their therapeutic effects, including administration routes, detection time-points, disease models, differentiation of MSCs in vivo, and timing and dosage of MSC administration. Finally, current approaches to allogeneic MSC application are discussed. In conclusion, allogeneic MSCs are a promising option because of their low immunogenicity and immunosuppressive and tissue repair capabilities. Further investigations are needed to enhance the consistency and efficacy of MSCs when used as a cell-based therapy in inflammatory diseases as well as for tissue repair.
\end{abstract}

\section{Introduction}

Mesenchymal stem cells (MSCs) are classified into various groups according to the cell source, such as bone marrow-derived MSCs (BM-MSCs), adipose-derived MSCs (ASCs), and umbilical cord MSCs. These MSC types share common features, which have been described by the International Society for Cellular Therapy. The

\footnotetext{
* Correspondence: wangyunchuan@fmmu.edu.cn; hudhai@sohu.com 'Department of Burns and Cutaneous Surgery, Xijing Hospital, Fourth Military Medical University, Xi'an, Shaanxi 710032, People's Republic of China Full list of author information is available at the end of the article
}

minimum criteria for defining MSCs are that they: (a) remain plastic-adherent under standard culture conditions; (b) express CD105, CD73, and CD90 and fail to express CD45, CD34, CD14 or CD11b, CD79a or CD19, and major histocompatibility complex (MHC) class II molecules; and (c) differentiate into osteoblasts, adipocytes, and chondrocytes in vitro [1].

The following unique properties appear to make MSCs ideal for cell-based therapy in various diseases. First, they have multilineage potential, differentiating into various cell types, including adipocytes, hepatocytes, and neurocytes [2-4]. This makes them useful as seed cells to replace damaged tissue in tissue engineering applications. Second, they alleviate tissue injury and promote tissue repair by their anti-apoptotic and cytoprotective effects and angiogenic capacity [5, 6]. Third, they have become a promising approach to treat graft-versus-host disease (GVHD) and autoimmune disease because of their immunomodulatory properties and low immunogenicity [7-9].

\section{Advantages of allogeneic MSCs for therapeutic applications}

Autologous MSC (auto-MSC) applications have some potential limitations. First, it is difficult to obtain sufficient auto-MSCs from some patients-for example, ASCs from thinner patients or BM-MSCs from myelofibrosis patients. Second, MSCs isolated from elderly donors have decreased biological activity, including differentiation and regenerative potential $[10,11]$, resulting in disappointing treatment outcomes. Third, some systemic diseases, such as diabetes [12], rheumatoid arthritis [13], and systemic lupus erythematosus (SLE) [14], alter the intrinsic properties of MSCs, thus impairing their protective function. It is difficult to obtain sufficient quantities of healthy autoMSCs with high activity from patients with these diseases. MSC implantation in these patients is therefore challenging. Obtaining allogeneic MSCs (allo-MSCs) from young 
healthy donors is a reasonable approach to resolving this issue.

Furthermore, auto-MSC extraction is time-consuming, making it difficult to use them promptly to treat acute diseases such as stroke and myocardial infarction. In contrast, allo-MSCs are readily available and can be administered immediately. In addition, commercial alloMSC production should guarantee quality control and reduce the cost of cell therapies. Therefore, allo-MSCs are promising alternatives to auto-MSCs, with advantages with regard to time, cost, and quality assurance.

Above all, the immunosuppressive properties and low immunogenicity of allo-MSCs contribute to a reduced immune response after implantation. The following mechanisms are responsible for their immunosuppression and low immunogenicity. First, their expression of a low or modest level of MHC class I molecules and lack of expression of MHC class II and co-stimulatory molecules, such as CD40, CD80 (B7-1), and CD86 (B7-2), leads to low immunogenicity, thus avoiding immune responses in recipients [15]. Second, MSCs inhibit the activity of various immune cells, including $\mathrm{T}$ cells, B cells, natural killer cells, and dendritic cells via cell-cell contacts and soluble factors $[16,17]$.

\section{Factors influencing the protective effect of allo-MSCs}

The concept that allo-MSCs may have equivalent efficacy to auto-MSCs has become well established. Increasingly, however, in vivo studies report that allo-MSCs are not fully immune privileged and probably cause an immune response despite the immunosuppressive properties and low immunogenicity of MSCs being documented both in vivo and in vitro. Currently, different research groups have obtained inconsistent or even contradictory results on the therapeutic effects of allo-MSCs in various studies [18-21]. Therefore, the in vivo immunogenicity of allo-MSCs and the relationship between immunogenicity and their protective effects remains to be determined. In addition, the cause of the inconsistent results has yet to be established. We describe in detail the factors that influence the therapeutic effects of allo-MSCs below.

\section{Administration routes versus therapeutic effects}

The routes of MSC administration are classified into two categories: systemic and topical. Some studies have reported that the administration route of allo-MSCs determines the extent of their protective effects.

There are two types of topical administration: intralesional injection (e.g., intracranial, intracerebral, subcutaneous) and local vascular injection (e.g., superior vena cava, mesenteric blood vessels, coronary artery). Compared with systemic administration, topical administration routes may have a common advantage in that MSCs arrive directly at the target tissue with little loss during migration $[18,22]$. It was demonstrated that allo-MSCs loaded onto cancellous bone granules have a similar efficacy to auto-MSCs for bone regeneration in bone defect models [23]. Acar et al. [24] reported that direct injection of allo-MSCs into marrow cavities (i.e., intrabone marrow delivery) had similar effects to intravenous (IV) injection in irradiation-damaged bone marrow repair. However, Gu et al. [25] reported that allo-MSCs implanted via the intrapancreatic route had a greater effect on hyperglycemia correction and increasing insulin secretion in the serum of diabetic rats than those administered via the IV route.

Types of systemic administration include IV, intraarterial, and intraperitoneal injection. IV is the most common method in preclinical and clinical settings because of its convenience. However, MSCs administered via this route are more easily trapped in small lung capillaries because of their larger size and expression of cell adhesion molecules [26, 27]. Lung entrapment of MSCs decreases the number of MSCs delivered to target tissues and can result in ineffectual treatment [28]. However, some reports have shown that auto-MSCs delivered via IV injection have protective effects in various animal models even when lung entrapment occurs $[3,29]$. Similar to autoMSCs, IV administration of allo-MSCs improved islet function and corrected hyperglycemia without immune rejection in a diabetic rat model [25]. In a rat ischemic stroke model, allogeneic ASCs and BM-MSCs delivered via IV injection decreased cell death, increased cellular proliferation, and improved the functional recovery of the brain [3].

Administration routes determine the microenvironments that MSCs first encounter after entering the patient's body, thus influencing their differentiation, immunogenicity, and survival [30]. However, the mechanisms responsible for these effects are far from clear because of the limited number of studies performed, and it is necessary to investigate which administration routes of MSCs are best for the diverse range of disease models.

\section{Evaluation time-points versus therapeutic effects}

Short-term (i.e., within a month) but not long-term protection has usually been evaluated in most studies that demonstrate the protective effects of MSCs [29, 31]. In contrast, most studies evaluating their long-term effect have shown no or limited protection [32, 33]. Therefore, the different time-points used in these investigations probably contribute to their different conclusions on the protective effects of MSCs. As MSCs have low immunogenicity but are not fully immune privileged in vivo, immune rejection of allo-MSCs is induced. However, this is too weak to eliminate them immediately, so alloMSCs can survive for a short period after transplantation. 
Therefore, they can exert a protective and/or immunosuppressive function in the short-term but are less effective in the long-term. More studies into implanted MSCs are urgently needed to simultaneously evaluate their shortand long-term protective effects.

\section{Disease models versus therapeutic effects}

It is well established that allo-MSCs can alleviate GVHD in the setting of allogeneic hematopoietic stem cell transplantation in preclinical [34] and clinical studies [35]. Moreover, the Prochymal brand of remestemcel-L, the first stem cell drug, has been approved for the market. Prochymal is a MSC product prepared from bone marrow aspirates of healthy human donors, and shows potential for treating acute GVHD [19, 36]. In addition to GVHD models, the efficacy and safety of allo-MSCs have been widely documented in autoimmune disease models. AlloMSCs can reduce the clinical relapse rate and improve the function of damaged organs in models of autoimmune diseases, including SLE and Crohn's disease [9, 37]. The technology available for allo-MSC applications for GVHD and Crohn's disease is currently comparatively mature; of the 13 available clinical trials on Prochymal registered in clinical trials databases, five have been for use in GVHD and Crohn's disease.

Although MSCs display a protective function in GVHD and autoimmune disease models, controversy exists about allo-MSC immunosuppression in the setting of solid organ transplantation [20, 38, 39]. For example, alloMSCs show no graft protection in many studies [20]. Unexpectedly, some studies have reported that allo-MSCs are ineffective at prolonging allograft survival and tend to cause more rapid-and a greater degree of-immune rejection [20, 21]. Therefore, the use of various disease models may be one reason for the controversy about the protective effects of allo-MSCs.

\section{Differentiation of MSCs in vivo versus therapeutic effects} The low immunogenicity of MSCs does not ensure they are fully immune privileged in an in vivo setting. AlloMSC immunogenicity after differentiation can weaken or even inhibit their therapeutic effects. Huang et al. [33] reported that expression of immunogenic MHC-Ia and MHC-II is strongly increased in differentiated MSCs compared with undifferentiated MSCs in a rat myocardial infarction model. The implanted allo-MSCs induced expression of a specific anti-donor alloantibody in serum after differentiation (5 weeks), which limited the longterm (more than 5 months) protective effects of MSCs on the heart. However, allo-MSCs were as effective as auto-MSCs in improving cardiac function for at least 3 months. In a diabetic rat model, Gu et al. [25] reported that implanted allo-MSCs did not express MHC-II and did not trigger cellular cytotoxicity and immune rejection until they differentiated into insulin-producing cells. Even so, the therapeutic effects of allo-MSCs for damaged pancreas were maintained after their differentiation.

From these results, we find that the presence of immunogenicity after differentiation decreases the therapeutic effects of allo-MSCs, although it does not indicate the definite loss of protective effects immediately, which is consistent with previous reports [40, 41]. We speculate on the probable reasons for this. First, even in specific induction conditions in vitro, only some MSCs differentiate; therefore, sufficient allo-MSCs remain in an undifferentiated state to ensure their survival and execute their protective effects on the immune systems of recipients. Second, the immunoreaction is too weak to quickly eliminate differentiated MSCs; a recipient's immune systems needs some time to eliminate all of the allo-MSCs. Current data on this issue are lacking and the specific protective mechanism that functions after differentiation needs to be further investigated.

\section{Timing of MSC administration versus therapeutic effect}

The immune status of a recipient before and after allograft organ transplantation determines the survival of implanted allo-MSCs. Crop et al. [42] reported that, before kidney transplantation, recipient peripheral blood mononuclear cells (PBMCs) did not lyse allo-MSCs, but that PBMCs isolated 3, 6, and 12 months after transplantation showed increasing ability to lyse allo-MSCs. In vivo experiments have shown that the different timing of auto-MSC transplantation determines their therapeutic effect in a myocardial infarction model [43]. As reported for auto-MSCs, a recent study by Rigol et al. [41] showed that allo-ASCs induce better neovascularization and a better long-term prognosis at $15 \mathrm{~min}$ after reperfusion than a week later. In addition, Cho et al. [44] reported that a single injection of MSCs, either systemically or subcutaneously, did not induce a detectable adaptive immune response. However, repeated injection of MSCs into the same site resulted in alloantibody production. Therefore, differences in administration timing have probably led to inconsistent conclusions regarding the immunogenicity and therapeutic effects of allo-MSCs.

\section{Dosage of MSC administration versus therapeutic effects}

Different doses of MSCs have different immune response or protective effects. Allo-MSCs injected intracranially induced transient dose-dependent immune rejection, which reduced MSC engraftment levels and their protective effects $[45,46]$. In contrast, an animal study on myocardial infarction by Wolf et al. [47] indicated that allo-MSCs limited myocardial infarct size and improved the functional outcome in a dose-dependent manner. Currently, the relationship between MSC dose and therapeutic effects is far from clear. Therefore, the optimal dose of implanted 
allo-MSCs needs to be further investigated to maximize their therapeutic function in various disease models.

\section{Application strategies for allogeneic MSCs}

Many unique features make MSCs a promising therapeutic option in tissue repair and immunosuppression. Although the direct application of allo-MSCs has a certain protective effect, various measures taken during or before transplantation can have a great effect on improving treatment outcomes (Table 1).

\section{Combined application with immunosuppressants}

The co-application of MSCs with immunosuppressants increases their protective effects compared with their separate application. On one hand, immunosuppressants improve the effects of MSCs by prolonging their survival time in allograft organ transplantation and, on the other, MSCs can decrease the side effects of immunosuppressants. For example, Ge et al. [48] observed that the immunosuppressant Rapa enabled successful MSC engraftment by suppressing the immune response to alloMSCs after heterotopic cardiac transplantation. Moreover, MSCs markedly enhanced the immunosuppressive effect of Rapa, thus enabling the dosage (and side effects) to be reduced [48]. MSCs attenuated acute immune rejection in renal transplantation, and had the potential benefit of reducing the dosage of the conventional immunosuppressant, tacrolimus [49].

Table 1 Strategies to enhance efficiency of MSC-based treatment

\begin{tabular}{|c|c|c|c|c|c|}
\hline Study & Method & Experimental model & $\begin{array}{l}\text { In vitro } \\
\text { or in vivo }\end{array}$ & Cell types & Conclusion \\
\hline $\begin{array}{l}\text { Maccario } \\
\text { et al. [64] }\end{array}$ & $\begin{array}{l}\text { Combination cyclosporine and } \\
\text { MSCs }\end{array}$ & - & In vitro & $\begin{array}{l}\text { Human } \\
\text { BM-MSCs }\end{array}$ & $\begin{array}{l}\text { Enhancement of the immunosuppressive effect } \\
\text { of MSCs }\end{array}$ \\
\hline $\begin{array}{l}\text { Buron } \\
\text { et al. [65] }\end{array}$ & $\begin{array}{l}\text { Combination mycophenolate } \\
\text { acid and MSCs }\end{array}$ & - & In vitro & $\begin{array}{l}\text { Human } \\
\text { BM-MSCs }\end{array}$ & $\begin{array}{l}\text { Enhancement of the immunosuppressive effect } \\
\text { of MSCs }\end{array}$ \\
\hline $\begin{array}{l}\text { Ge } \\
\text { et al. [48] }\end{array}$ & $\begin{array}{l}\text { Combination rapamycin and } \\
\text { MSCs }\end{array}$ & $\begin{array}{l}\text { Allogeneic cardiac } \\
\text { transplantation (mouse) }\end{array}$ & In vivo & $\begin{array}{l}\text { Mouse } \\
\text { BM-MSCs }\end{array}$ & $\begin{array}{l}\text { Attenuation of alloimmune responses and } \\
\text { promotion of cardiac allograft tolerance }\end{array}$ \\
\hline $\begin{array}{l}\text { Peng } \\
\text { et al. [49] }\end{array}$ & $\begin{array}{l}\text { Combination tacrolimus and } \\
\text { MSCs }\end{array}$ & $\begin{array}{l}\text { Allogeneic renal } \\
\text { transplantation (human) }\end{array}$ & In vivo & $\begin{array}{l}\text { Human } \\
\text { BM-MSCs }\end{array}$ & $\begin{array}{l}\text { Induction of donor-specific graft tolerance and } \\
\text { maintaining long-term graft survival and function }\end{array}$ \\
\hline $\begin{array}{l}\text { de la Garza- } \\
\text { Rodea } \\
\text { et al. [53] }\end{array}$ & $\begin{array}{l}\text { MSCS transfected with US11 } \\
\text { gene from HCMV }\end{array}$ & NOD/SCID (mouse) & In vivo & $\begin{array}{l}\text { Human } \\
\text { BM-MSCS }\end{array}$ & $\begin{array}{l}\text { Down-regulation of MHC class I surface expression } \\
\text { and preventing rejection of xenogeneic MSCs }\end{array}$ \\
\hline $\begin{array}{l}\text { Soland } \\
\text { et al. [66] }\end{array}$ & $\begin{array}{l}\text { MSCs transfected with US6 } \\
\text { gene and US11 gene from } \\
\text { HCMV }\end{array}$ & $\begin{array}{l}\text { In utero transplantation } \\
\text { of fetuses (sheep) }\end{array}$ & In vivo & $\begin{array}{l}\text { Human fetal } \\
\text { liver-derived } \\
\text { MSCs }\end{array}$ & $\begin{array}{l}\text { Decreasing recognition of MSCS by the immune } \\
\text { system and enhancing engraftment of MSC-US11 } \\
\text { and MSC-US6 in fetal sheep liver }\end{array}$ \\
\hline $\begin{array}{l}\text { Levy } \\
\text { et al. [67] }\end{array}$ & $\begin{array}{l}\text { MSCs transfected with } / L-10 \\
\text { gene }\end{array}$ & $\begin{array}{l}\text { Inflammation of ears } \\
\text { (mouse) }\end{array}$ & In vivo & $\begin{array}{l}\text { Mouse } \\
\text { BM-MSCs }\end{array}$ & $\begin{array}{l}\text { Improvement of immunosuppressive properties } \\
\text { and anti-inflammatory effect }\end{array}$ \\
\hline $\begin{array}{l}\text { Sullivan } \\
\text { et al. [54] }\end{array}$ & $\begin{array}{l}\text { MSCs transfected with Ctla4ig } \\
\text { gene }\end{array}$ & $\begin{array}{l}\text { Inflammatory arthritis } \\
\text { (mouse) }\end{array}$ & In vivo & $\begin{array}{l}\text { Mouse } \\
\text { BM-MSCs }\end{array}$ & $\begin{array}{l}\text { Improvement of the homing and delaying the } \\
\text { onset of inflammatory arthritis }\end{array}$ \\
\hline $\begin{array}{l}\text { Chen } \\
\text { et al. [55] }\end{array}$ & $\begin{array}{l}\text { MSCs transduced with } \mathrm{CXCr}-4 \\
\text { gene }\end{array}$ & $\begin{array}{l}\text { Allogeneic bone marrow } \\
\text { transplantation (mouse) }\end{array}$ & In vivo & $\begin{array}{l}\text { Mouse } \\
\text { BM-MSCs }\end{array}$ & $\begin{array}{l}\text { Promoting recovery of HSCs and hematopoietic } \\
\text { organs }\end{array}$ \\
\hline $\begin{array}{l}\text { Eliopoulos } \\
\text { et al. [56] }\end{array}$ & Epo gene enhanced MSCs & $\begin{array}{l}\text { Acute renal injury } \\
\text { (mouse) }\end{array}$ & In vivo & $\begin{array}{l}\text { Mouse } \\
\text { BM-MSCs }\end{array}$ & $\begin{array}{l}\text { Augmenting the protective properties of MSCs } \\
\text { and increasing the survival rate of mouse }\end{array}$ \\
\hline $\begin{array}{l}\text { Yuan } \\
\text { et al. [59] }\end{array}$ & $\begin{array}{l}\text { Combination MSCs and } \\
\text { hydrogels }\end{array}$ & Normal rabbit & In vivo & $\begin{array}{l}\text { Rabbit } \\
\text { BM-MSCs }\end{array}$ & $\begin{array}{l}\text { Augmenting the isolation from the host immune } \\
\text { system and attenuating severe immune rejection }\end{array}$ \\
\hline $\begin{array}{l}\text { Dhingra } \\
\text { et al. [58] }\end{array}$ & $\begin{array}{l}\text { Combination MSCs and } \\
\text { biodegradable hydrogels } \\
\text { that slowly released PGE2 }\end{array}$ & $\begin{array}{l}\text { Myocardial infarction } \\
\text { (rat) }\end{array}$ & In vivo & $\begin{array}{l}\text { Rat } \\
\text { BM-MSCS }\end{array}$ & $\begin{array}{l}\text { Preventing rejection of implanted MSCs and } \\
\text { restoring cardiac function }\end{array}$ \\
\hline $\begin{array}{l}\text { Sarkar } \\
\text { et al. [57] }\end{array}$ & $\begin{array}{l}\text { MSCs engineered with PLGA } \\
\text { particles containing } \\
\text { dexamethasone }\end{array}$ & - & In vitro & $\begin{array}{l}\text { Human } \\
\text { BM-MSCs }\end{array}$ & $\begin{array}{l}\text { Controlling the differentiation of particle-carrying } \\
\text { cells }\end{array}$ \\
\hline $\begin{array}{l}\text { Ko et al. } \\
\text { [68] }\end{array}$ & $\begin{array}{l}\text { MSCs coated with PPG } \\
\text { followed by antibodies } \\
\text { to ICAM-1 }\end{array}$ & - & In vitro & $\begin{array}{l}\text { Mouse } \\
\text { BM-MSCs }\end{array}$ & $\begin{array}{l}\text { Promoting the attachment of MSCs to endothelial } \\
\text { cells }\end{array}$ \\
\hline $\begin{array}{l}\text { Sarkar } \\
\text { et al. [69] }\end{array}$ & $\begin{array}{l}\text { MSCs engineered with lipid } \\
\text { vesicles to present biomolecular } \\
\text { ligands }\end{array}$ & - & In vitro & $\begin{array}{l}\text { Human } \\
\text { BM-MSCS }\end{array}$ & $\begin{array}{l}\text { Immobilizing adhesion ligands and promoting } \\
\text { the homing of MSCs }\end{array}$ \\
\hline
\end{tabular}




\section{Genetic modification of MSCs}

The effectiveness of genetically modified auto-MSCs has been reported in different disease models [50-52]. Similarly, the protective effect of allo-MSCs was improved by gene modification. de la Garza-Rodea et al. [53] observed that BM-MSCs with a modified US11 gene led to decreasing expression of MHC-1. The US11 gene modification contributed to evasion of recognition by cytotoxic lymphocytes and extended the persistence of MSCs in the allogeneic host. In contrast to wild-type alloMSCs, allo-MSCs expressing cytotoxic $\mathrm{T}$ lymphocyte associated antigen-4 (CTLA4Ig) demonstrated enhanced inhibition of T-cell responses [54]. The genetically modified MSCs delayed the onset of inflammatory arthritis and decreased the amount of damage in collagen-induced arthritis. Chen et al. [55] reported that MSCs expressing allogeneic C-X-C chemokine receptor type 4 (CXCR-4) promoted a greater level of hematopoietic recovery and sustained hematopoiesis compared with unmodified MSCs. The protection of MSCs resulted from the enhanced ability to home to bone marrow and spleen. Allo-MSCs with modified Epo gene significantly increased protective effects for kidney and improved the survival of mice in an acute kidney injury model [56].

\section{Method of cell engineering}

The fate of implanted allo-MSCs is tightly influenced by the microenvironment encountered. Intracellular depots have been generated through cell engineering to provide controlled microenvironments for MSCs. These depots continuously release drugs and cellular factors which affect the homing, viability, differentiation of MSCs, etc. For example, MSCs engineered with poly lactide-coglycolic acid particles containing dexamethasone promoted the osteogenic differentiation of MSCs [57].

Hydrogels were previously reported to be promising allo-MSC carriers for tissue engineering. Dhingra et al. [58] reported that the use of a biodegradable, temperature-sensitive hydrogel for the slow release of prostaglandin E2 at the cell implantation site could prevent rejection of implanted allo-MSCs and restore cardiac function in a myocardial infarction model. Interestingly, hydrogels themselves have been documented to modulate the immunological properties of allo-MSC tissue-engineered cartilage. Neonatal rabbit allo-MSCs induced lower allogeneic lymphocyte proliferation and reduced the expression of MHC class I and II molecules when seeded in a collagen hydrogel compared with sponge and membrane [59].

Recently, there have been fewer studies on applications of allo-MSCs compared with auto-MSCs. Auto-MSC studies have provided insight into allo-MSC applications. For example, the pre-stimulation of auto-MSCs with interferon-gamma increased their immunosuppressive capacity, reduced mucosal damage, and enhanced their therapeutic efficacy in animal models of colitis [60]. In addition, hypoxia preconditioning is reported to increase the protective effect of auto-MSCs in disease models such as hemorrhagic stroke [61], ischemia [62], and pulmonary fibrosis [63].

\section{Conclusion and future perspectives}

MSCs have shown promise in cell replacement or transplantation for their immunosuppressive and tissue repair effects. However, it is difficult to isolate sufficient quantities of healthy auto-MSCs with high activity from older or thinner people and patients with diabetes, rheumatoid arthritis or SLE. Moreover, auto-MSCs are not suited to the prompt treatment of acute diseases because extraction of them is time-consuming. Because of their immune suppression properties and low immunogenicity compared with other cell types, the implantation of allo-MSCs may, therefore, be more reasonable and appropriate. Although various studies have provided inconsistent conclusions on the therapeutic effects of allo-MSCs, allo-MSCs are still a promising option in immunosuppressive and tissue repair therapy.

To date, we have been unable to obtain consistent results from the insufficient pre-clinical and clinical data on the immunogenicity and protective effects of allo-MSCs. The following issues need to be addressed in further research. First, which immune molecules and cells are involved in the potential immune response? Second, what is the dynamic fate of implanted allogeneic ASCs, including being eliminated by recipients, being maintained in the stem cell state, or differentiating into various cell types? It will be helpful to assess the in vivo efficiency of allo-MSCs compared with that of auto-MSCs. Third, the factors that influence their therapeutic effects and how they result in the present inconsistent results are far from clear. Last, strategies to enhance the consistency and efficacy of allo-MSCs as a cell-based therapy should be investigated in inflammatory diseases as well as for tissue repair.

\section{Abbreviations \\ allo-MSC: allogeneic mesenchymal stem cell; ASC: adipose-derived mesenchymal stem cell; auto-MSC: autologous mesenchymal stem cell; BM-MSC: bone marrow-derived mesenchymal stem cell; GVHD: graft-versus- host disease; IV: intravenous; MHC: major histocompatibility complex; MSC: mesenchymal stem cell; PBMC: peripheral blood mononuclear cell; SLE: systemic lupus erythematosus.}

Competing interests

The authors declare that they have no competing interests.

\section{Authors' contributions}

$\mathrm{JZ}$ contributed to the research design and wrote the manuscript. $\mathrm{XH}$ and HW participated in the research design, drafting the manuscript and carrying out the literature research. $X L$ and TZ were involved in carrying out the literature research and revising the manuscript critically for important intellectual content. YW and DH contributed to the research design, drafting 
the manuscript and revising it critically for important intellectual content. All authors read and approved the final manuscript.

\section{Acknowledgments}

We express our gratitude to Dr. Jinsong Chen and Dr. Zhi Mao for their expert suggestions regarding the manuscript. This work is financially supported by the National Nature Science Foundation of China (81372078) (81301632).

\section{Author details}

${ }^{1}$ Department of Burns and Cutaneous Surgery, Xijing Hospital, Fourth Military Medical University, Xi'an, Shaanxi 710032, People's Republic of China. ${ }^{2}$ Department of Burn and Plastic Surgery, the 205th Hospital of People's Liberation Army, Jinzhou, Liaoning 121000, PR China. ${ }^{3}$ Changchun Zhongyan Medical Cosmetic Hospital, Changchun, Jilin 130000, PR China. ${ }^{4}$ Department of Plastic Surgery, General Hospital of Shenyang Military Area Command of People's Liberation Army, Shenyang, Liaoning 110016, PR China. ${ }^{5}$ Department Of Neurology, the 303th Hospital of People's Liberation Army, Nanning, Guangxi 530021, PR China.

\section{Published online: 01 December 2015}

\section{References}

1. Dominici M, Le Blanc K, Mueller I, Slaper-Cortenbach I, Marini F, Krause D, et al. Minimal criteria for defining multipotent mesenchymal stromal cells. The International Society for Cellular Therapy position statement. Cytotherapy. 2006;8:315-7.

2. Fu S, Luan J, Xin MQ, Wang Q, Xiao R, Gao YZ. Fate of adipose-derived stromal vascular fraction cells after co-implantation with fat grafts: evidence of cell survival and differentiation in ischemic adipose tissue. Plast Reconstr Surg. 2013;132:363-73.

3. Gutierrez-Fernandez M, Rodriguez-Frutos B, Ramos-Cejudo J, Teresa Vallejo-Cremades M, Fuentes B, Cerdan S, et al. Effects of intravenous administration of allogenic bone marrow- and adipose tissue-derived mesenchymal stem cells on functional recovery and brain repair markers in experimental ischemic stroke. Stem Cell Res Ther. 2013;4:11.

4. Wu XB, Tao R. Hepatocyte differentiation of mesenchymal stem cells. Hepatobiliary Pancreat Dis Int. 2012;11:360-71.

5. Li JH, Zhang N, Wang JA. Improved anti-apoptotic and anti-remodeling potency of bone marrow mesenchymal stem cells by anoxic pre-conditioning in diabetic cardiomyopathy. J Endocrinol Invest. 2008;31:103-10.

6. Liu XB, Wang JA, Ji XY, Yu SP, Wei L. Preconditioning of bone marrow mesenchymal stem cells by prolyl hydroxylase inhibition enhances cell survival and angiogenesis in vitro and after transplantation into the ischemic heart of rats. Stem Cell Res Ther. 2014;5:111.

7. El-Jawhari JJ, El-Sherbiny YM, Jones EA, McGonagle D. Mesenchymal stem cells, autoimmunity and rheumatoid arthritis. QJM. 2014;107:505-14.

8. Amorin B, Alegretti AP, Valim V, Pezzi A, Laureano AM, da Silva MA, et al. Mesenchymal stem cell therapy and acute graft-versus-host disease: a review. Hum Cell. 2014;27:137-50.

9. Wang D, Zhang H, Liang J, Li X, Feng X, Wang H, et al. Allogeneic mesenchymal stem cell transplantation in severe and refractory systemic lupus erythematosus: 4 years of experience. Cell Transplant. 2013;22:2267-77.

10. Jung HG, Ahn EK, Lee JH, Kim YH, Leem SH, Heo J, et al. Effects of harvesting sites and ages on adipose tissue-derived stem cells in rat. Tissue Eng Regen Med. 2014;11:137-42.

11. Mueller SM, Glowacki J. Age-related decline in the osteogenic potential of human bone marrow cells cultured in three-dimensional collagen sponges. J Cell Biochem. 2001;82:583-90.

12. Cianfarani F, Toietta G, Di Rocco G, Cesareo E, Zambruno G, Odorisio T. Diabetes impairs adipose tissue-derived stem cell function and efficiency in promoting wound healing. Wound Repair Regen. 2013;21:545-53.

13. Sun Y, Deng W, Geng L, Zhang L, Liu R, Chen W, et al. Mesenchymal stem cells from patients with rheumatoid arthritis display impaired function in inhibiting Th17 cells. J Immunol Res. 2015;2015:284215.

14. Nie Y, Lau C, Lie A, Chan G, Mok M. Defective phenotype of mesenchymal stem cells in patients with systemic lupus erythematosus. Lupus. 2010;19:850-9.

15. Lohan P, Coleman CM, Murphy JM, Griffin MD, Ritter T, Ryan AE. Changes in immunological profile of allogeneic mesenchymal stem cells after differentiation: should we be concerned? Stem Cell Res Ther. 2014;5:99.
16. Zhao ZG, Xu W, Sun L, You Y, Li F, Li QB, et al. Immunomodulatory function of regulatory dendritic cells induced by mesenchymal stem cells. Immunol Invest. 2012;41:183-98.

17. Griffin MD, Ryan AE, Alagesan S, Lohan P, Treacy O, Ritter T. Anti-donor immune responses elicited by allogeneic mesenchymal stem cells: what have we learned so far? Immunol Cell Biol. 2013;91:40-51.

18. Kim I, Bang SI, Lee SK, Park SY, Kim M, Ha H. Clinical implication of allogenic implantation of adipogenic differentiated adipose-derived stem cells. Stem Cells Transl Med. 2014;3:1312-21.

19. Kurtzberg J, Prockop S, Teira P, Bittencourt H, Lewis V, Chan KW, et al. Allogeneic human mesenchymal stem cell therapy (remestemcel-L, Prochymal) as a rescue agent for severe refractory acute graft-versus-host disease in pediatric patients. Biol Blood Marrow Transplant. 2014;20:229-35.

20. Sbano P, Cuccia A, Mazzanti B, Urbani S, Giusti B, Lapini I, et al. Use of donor bone marrow mesenchymal stem cells for treatment of skin allograft rejection in a preclinical rat model. Arch Dermatol Res. 2008;300:115-24.

21. Seifert M, Stolk M, Polenz D, Volk HD. Detrimental effects of rat mesenchymal stromal cell pre-treatment in a model of acute kidney rejection. Front Immunol. 2012;3:202.

22. Hare JM, Fishman JE, Gerstenblith G, DiFede Velazquez DL, Zambrano JP, Suncion VY, et al. Comparison of allogeneic vs autologous bone marrowderived mesenchymal stem cells delivered by transendocardial injection in patients with ischemic cardiomyopathy: the POSEIDON randomized trial. JAMA. 2012;308:2369-79.

23. Kang $\mathrm{SH}$, Chung YG, Oh IH, Kim YS, Min KO, Chung JY. Bone regeneration potential of allogeneic or autogeneic mesenchymal stem cells loaded onto cancellous bone granules in a rabbit radial defect model. Cell Tissue Res. 2014;355:81-8.

24. Acar U, Pinarli FA, Acar DE, Beyazyildiz E, Sobaci G, Ozgermen BB, et al. Effect of allogeneic limbal mesenchymal stem cell therapy in corneal healing: role of administration route. Ophthalmic Res. 2015;53:82-9.

25. Gu LH, Zhang TT, Li Y, Yan HJ, Qi H, Li FR. Immunogenicity of allogeneic mesenchymal stem cells transplanted via different routes in diabetic rats. Cell Mol Immunol. 2014;12:444-55.

26. Fischer UM, Harting MT, Jimenez F, Monzon-Posadas WO, Xue H, Savitz SI, et al. Pulmonary passage is a major obstacle for intravenous stem cell delivery: the pulmonary first-pass effect. Stem Cells Dev. 2009;18:683-92.

27. Nystedt J, Anderson H, Tikkanen J, Pietila M, Hirvonen T, Takalo R, et al. Cell surface structures influence lung clearance rate of systemically infused mesenchymal stromal cells. Stem Cells. 2013;31:317-26.

28. Makela T, Takalo R, Arvola O, Haapanen H, Yannopoulos F, Blanco R, et al. Safety and biodistribution study of bone marrow-derived mesenchymal stromal cells and mononuclear cells and the impact of the administration route in an intact porcine model. Cytotherapy. 2015;17:392-402.

29. Choi EW, Shin IS, Park SY, Yoon EJ, Kang SK, Ra JC, et al. Characteristics of mouse adipose tissue-derived stem cells and therapeutic comparisons between syngeneic and allogeneic adipose tissue-derived stem cell transplantation in experimental autoimmune thyroiditis. Cell Transplant. 2014;23:873-87.

30. Nemeth K. Mesenchymal stem cell therapy for immune-modulation: the donor, the recipient, and the drugs in-between. Exp Dermatol. 2014;23:625-8.

31. Ishikane S, Yamahara K, Sada M, Harada K, Kodama M, Ishibashi-Ueda H, et al. Allogeneic administration of fetal membrane-derived mesenchymal stem cells attenuates acute myocarditis in rats. J Mol Cell Cardiol. 2010;49:753-61.

32. Liang J, Li X, Zhang H, Wang D, Feng X, Wang $H$, et al. Allogeneic mesenchymal stem cells transplantation in patients with refractory RA. Clin Rheumatol. 2012;31:157-61.

33. Huang XP, Sun Z, Miyagi Y, McDonald Kinkaid H, Zhang L, Weisel RD, et al. Differentiation of allogeneic mesenchymal stem cells induces immunogenicity and limits their long-term benefits for myocardial repair. Circulation. 2010;122:2419-29.

34. Jang MJ, Kim HS, Lee HG, Kim GJ, Jeon HG, Shin HS, et al. Placenta-derived mesenchymal stem cells have an immunomodulatory effect that can control acute graft-versus-host disease in mice. Acta Haematol. 2013;129:197-206.

35. Muroi K, Miyamura K, Ohashi K, Murata M, Eto T, Kobayashi N, et al. Unrelated allogeneic bone marrow-derived mesenchymal stem cells for steroid-refractory acute graft-versus-host disease: a phase I/|| study. Int J Hematol. 2013;98:206-13.

36. Prasad VK, Lucas KG, Kleiner GI, Talano JA, Jacobsohn D, Broadwater G, et al. Efficacy and safety of ex vivo cultured adult human mesenchymal stem 
cells (Prochymal) in pediatric patients with severe refractory acute graftversus-host disease in a compassionate use study. Biol Blood Marrow Transplant. 2011;17:534-41.

37. Wainstein C, Quera R, Kronberg U, Conejero A, Lopez-Kostner F, Jofre C, et al. Mesenchymal stem cells and platelet-rich plasma in the treatment of patients with perineal Crohn's disease. Int J Colorectal Dis. 2015. [Epub ahead of print].

38. Inoue S, Popp FC, Koehl GE, Piso P, Schlitt HJ, Geissler EK, et al. Immunomodulatory effects of mesenchymal stem cells in a rat organ transplant model. Transplantation. 2006:81:1589-95.

39. Moreno R, Martinez-Gonzalez I, Rosal M, Nadal M, Petriz J, Gratacos E, et al. Fetal liver-derived mesenchymal stem cell engraftment after allogeneic in utero transplantation into rabbits. Stem Cells Dev. 2012;21:284-95.

40. Chatterjea A, LaPointe VL, Alblas J, Chatterjea S, van Blitterswijk CA, de Boer J. Suppression of the immune system as a critical step for bone formation from allogeneic osteoprogenitors implanted in rats. J Cell Mol Med. 2014:18:134-42.

41. Rigol M, Solanes N, Roura S, Roque M, Novensa L, Dantas AP, et al. Allogeneic adipose stem cell therapy in acute myocardial infarction. Eur J Clin Invest. 2014;44:83-92.

42. Crop MJ, Korevaar SS, de Kuiper R, IJzermans JN, van Besouw NM, Baan CC, et al. Human mesenchymal stem cells are susceptible to lysis by CD8(+) T cells and NK cells. Cell Transplant. 2011;20:1547-59.

43. Hu X, Wang J, Chen J, Luo R, He A, Xie X, et al. Optimal temporal delivery of bone marrow mesenchymal stem cells in rats with myocardial infarction. Eur J Cardiothorac Surg. 2007;31:438-43.

44. Cho PS, Messina DJ, Hirsh EL, Chi N, Goldman SN, Lo DP, et al. Immunogenicity of umbilical cord tissue derived cells. Blood. 2008:111:430-8.

45. Isakova IA, Dufour J, Lanclos C, Bruhn J, Phinney DG. Cell-dosedependent increases in circulating levels of immune effector cells in rhesus macaques following intracranial injection of allogeneic MSCs. Exp Hematol. 2010;38:957-67. e1.

46. Isakova IA, Lanclos C, Bruhn J, Kuroda MJ, Baker KC, Krishnappa V, et al. Allo-reactivity of mesenchymal stem cells in rhesus macaques is dose and haplotype dependent and limits durable cell engraftment in vivo. PLoS One. 2014;9, e87238.

47. Wolf D, Reinhard A, Seckinger A, Katus HA, Kuecherer H, Hansen A. Dosedependent effects of intravenous allogeneic mesenchymal stem cells in the infarcted porcine heart. Stem Cells Dev. 2009;18:321-9.

48. Ge W, Jiang J, Baroja ML, Arp J, Zassoko R, Liu W, et al. Infusion of mesenchymal stem cells and rapamycin synergize to attenuate alloimmune responses and promote cardiac allograft tolerance. Am J Transplant. 2009:9:1760-72.

49. Peng $Y, K e ~ M, X u L$, Liu L, Chen X, Xia W, et al. Donor-derived mesenchymal stem cells combined with low-dose tacrolimus prevent acute rejection after renal transplantation: a clinical pilot study. Transplantation. 2013;95:161-8.

50. Castro-Govea Y, Cervantes-Kardasch VH, Borrego-Soto G, Martinez-Rodriguez HG, Espinoza-Juarez M, Romero-Diaz V, et al. Human bone morphogenetic protein 2-transduced mesenchymal stem cells improve bone regeneration in a model of mandible distraction surgery. J Craniofac Surg. 2012;23:392-6.

51. Li Y, Yan M, Yang J, Raman I, Du Y, Min S, et al. Glutathione S-transferase Mu 2-transduced mesenchymal stem cells ameliorated anti-glomerular basement membrane antibody-induced glomerulonephritis by inhibiting oxidation and inflammation. Stem Cell Res Ther. 2014;5:19.

52. Zheng $Y, Y i$, Xia W, Ding T, Zhou Z, Han Y, et al. Mesenchymal stem cells transduced by vascular endothelial growth factor gene for ischemic random skin flaps. Plast Reconstr Surg. 2008;121:59-69.

53. de la Garza-Rodea AS, Verweij MC, Boersma H, van der Velde-van Dijke I, de Vries AA, Hoeben RC, et al. Exploitation of herpesvirus immune evasion strategies to modify the immunogenicity of human mesenchymal stem cell transplants. PLoS One. 2011;6, e14493.

54. Sullivan C, Barry F, Ritter T, O'Flatharta C, Howard L, Shaw G, et al. Allogeneic murine mesenchymal stem cells: migration to inflamed joints in vivo and amelioration of collagen induced arthritis when transduced to express CTLA4Ig. Stem Cells Dev. 2013;22:3203-13.

55. Chen W, Li M, Su G, Zang Y, Yan Z, Cheng H, et al. Co-transplantation of hematopoietic stem cells and cxcr4 gene-transduced mesenchymal stem cells promotes hematopoiesis. Cell Biochem Biophys. 2014. [Epub ahead of print].

56. Eliopoulos N, Zhao J, Forner K, Birman E, Young YK, Bouchentouf M. Erythropoietin gene-enhanced marrow mesenchymal stromal cells decrease cisplatin-induced kidney injury and improve survival of allogeneic mice. Mol Ther. 2011;19:2072-83.

57. Sarkar D, Ankrum JA, Teo GS, Carman CV, Karp JM. Cellular and extracellular programming of cell fate through engineered intracrine-, paracrine-, and endocrine-like mechanisms. Biomaterials. 2011;32:3053-61.

58. Dhingra S, Li P, Huang XP, Guo J, Wu J, Mihic A, et al. Preserving prostaglandin E2 level prevents rejection of implanted allogeneic mesenchymal stem cells and restores postinfarction ventricular function. Circulation. 2013;128:569-78.

59. Yuan T, Li K, Guo L, Fan H, Zhang X. Modulation of immunological properties of allogeneic mesenchymal stem cells by collagen scaffolds in cartilage tissue engineering. J Biomed Mater Res A. 2011;98:332-41.

60. Duijvestein M, Wildenberg ME, Welling MM, Hennink S, Molendijk I, van Zuylen $\mathrm{VL}$, et al. Pretreatment with interferon-gamma enhances the therapeutic activity of mesenchymal stromal cells in animal models of colitis. Stem Cells. 2011;29:1549-58.

61. Sun J, Wei ZZ, Gu X, Zhang JY, Zhang Y, Li J, et al. Intranasal delivery of hypoxia-preconditioned bone marrow-derived mesenchymal stem cells enhanced regenerative effects after intracerebral hemorrhagic stroke in mice. Exp Neurol. 2015. doi:10.1016/j.expneurol.2015.03.011.

62. Liu J, Hao H, Xia L, Ti D, Huang H, Dong L, et al. Hypoxia pretreatment of bone marrow mesenchymal stem cells facilitates angiogenesis by improving the function of endothelial cells in diabetic rats with lower ischemia. PLoS One. 2015;10, e0126715.

63. Lan YW, Choo KB, Chen CM, Hung TH, Chen YB, Hsieh CH, et al. Hypoxiapreconditioned mesenchymal stem cells attenuates bleomycin-induced pulmonary fibrosis. Stem Cell Res Ther. 2015;6:97.

64. Maccario R, Moretta A, Cometa A, Montagna D, Comoli P, Locatelli F, et al. Human mesenchymal stem cells and cyclosporin a exert a synergistic suppressive effect on in vitro activation of alloantigen-specific cytotoxic lymphocytes. Biol Blood Marrow Transplant. 2005;11:1031-2.

65. Buron F, Perrin $\mathrm{H}$, Malcus $\mathrm{C}$, Hequet $\mathrm{O}$, Thaunat $\mathrm{O}$, Kholopp-Sarda MN, et al. Human mesenchymal stem cells and immunosuppressive drug interactions in allogeneic responses: an in vitro study using human cells. Transplant Proc. 2009;41:3347-52.

66. Soland MA, Bego MG, Colletti E, Porada CD, Zanjani ED, St Jeor S, et al. Modulation of human mesenchymal stem cell immunogenicity through forced expression of human cytomegalovirus us proteins. PLoS One. 2012;7, e36163.

67. Levy O, Zhao W, Mortensen L, Leblanc S, Tsang K, Fu M, et al. mRNAengineered mesenchymal stem cells for targeted delivery of interleukin-10 to sites of inflammation. Blood. 2013;122:e23-32.

68. Ko IK, Kean TJ, Dennis JE. Targeting mesenchymal stem cells to activated endothelial cells. Biomaterials. 2009;30:3702-10.

69. Sarkar D, Vemula PK, Zhao W, Gupta A, Karnik R, Karp JM. Engineered mesenchymal stem cells with self-assembled vesicles for systemic cell targeting. Biomaterials. 2010;31:5266-74. 